\title{
Interspecific Interaction Between Phytoseiulus macropilis and Neoseiulus californicus (Acari: Phytoseiidae) Preying on Tetranychus urticae (Acari: Tetranychidae) on Rosebush Growing in Greenhouse

\author{
Giselle Christiane Souza-Pimentel ${ }^{1}$, Paulo Rebelles Reis ${ }^{2 *}$, Gilberto Rodrigues Liska ${ }^{3}$,
} Marcelo Ângelo Cirillo ${ }^{4}$

\author{
*Corresponding author: Email: paulo.rebelles@epamig.ufla.br \\ ${ }^{3}$ D.Sc. Universidade Federal do Pampa - UNIPAMPA \\ ${ }^{4}$ D.Sc. Universidade Federal de Lavras - UFLA, Departamento de Ciências Exatas
} \\ ${ }^{1}$ D.Sc. Postgraduate Program, Universidade Federal de Lavras - UFLA, Lavras, MG, Brazil. \\ ${ }^{2}$ D.Sc. Empresa de Pesquisa Agropecuária de Minas Gerais - EPAMIG Sul de Minas/EcoCentro and CNPq
}

\begin{abstract}
Greenhouses provide favorable conditions to grow roses (Rosa spp.) but also for the pest mite Tetranychus urticae Koch (Acari: Tetranychidae). Although chemical control continues to be used against this pest, consumer demand has encouraged research on less aggressive agricultural practices and biological control is now a viable option. The objective of this study was to investigate biological control of the two-spotted mite, in rosebush growing in greenhouse, by Phytoseiulus macropilis (Banks) and Neoseiulus californicus (McGregor) (Acari: Phytoseiidae), individually or in combination. Potted rosebushes (Rosa alba L., Rosaceae) were used in five treatments: 1 - control group, rosebushes only with T. urticae; 2 - rosebushes with T. urticae and N. californicus; 3 - rosebushes with T. urticae and P. macropilis; 4 rosebushes with T. urticae, N. californicus, and, after 4 weeks, P. macropilis and 5 - rosebushes with T. urticae, N. californicus, and P. macropilis. Biological control was evaluated by counting live mites. The results showed that both predatory mites were efficient in the control of the two-spotted mite on rosebushes cultivated in the greenhouse, either alone or in combination, but, when only P. macropilis was released, this predaceous mite was more efficient than N. californicus, at either low or high prey density, but the N. californicus can survive for longer in the absence of prey or in its low presence, for being a generalist predatory mite.
\end{abstract}

Keywords—Biological control, Rosa spp., Two-spotted spider mite, Protected crop, Agricultural acarology.

\section{INTRODUCTION}

The flower trade in Brazil is growing and emerging as a highly profitable business sector. In 2014, the sector gained approximately US $\$ 1.42$ billion, and $8 \%$ growth is estimated for 2015 [1].

The state of Minas Gerais, Brazil, is a leader in this sector, particularly for the production of rosebushes (Rosa spp.) and other conventional cutting flowers. Although up-to-date data for this activity in Minas Gerais are not available, the primary municipalities for flower production in this state are Barbacena, Andradas, Araxá, and Munhoz [2].

The Asian rosebush grows well in Brazil and is cultivated in various Brazilian regions, with much of the production in greenhouses. Although the greenhouse environment provides better conditions for the control of pests and diseases, the environment is also more favorable for pests and diseases to develop. The two-spotted spider mite, Tetranychus urticae Koch (Acari: Tetranychidae), is a pest mite that deserves special attention as one of the major problems to affect rosebushes in protected cultivation systems [3].

Pest control is one of the challenges for the cultivation of flowers and ornamental plants, because any damage caused by insects and other arthropods to flowers and foliage makes them unacceptable to consumers, and therefore depreciates the final product to be marketed [4].

Although producers and consumers strongly demand reduced use of agrochemicals [5], the spraying of chemical pesticides remains the primary tactic for the control of pests and diseases. Spraying is often used for prevention [6], which causes ecological disequilibrium and environmental contamination in many cases [7], particularly when these products are misused, such as erroneous doses of plant protection products, unnecessary spraying beyond recommended, use of unregistered products for the crop etc. 
The concerns of consumers for human health and environmental preservation have encouraged researchers to investigate the use of less aggressive agricultural practices that promote sustainability in agroecosystems [6]. Therefore, in the ecological management of pests, practices that preserve natural enemies in the environment are essential, and the use of selective products that minimize harmful effects to non-target fauna and maintain the ecological balance of the agroecosystem is indispensable [8].

Biological control is an important alternative for pest management. In addition to providing efficient control, biological control can add value to an agricultural product when well-planned and implemented, because an image can be established for consumers of a product that is produced ecologically [9].

The predatory mites Neoseiulus californicus (McGregor) and Phytoseiulus macropilis (Banks) (Acari: Phytoseiidae), among others, are used for the biological control of two-spotted spider mites on fruit trees, ornamental plants, and other crops. This method of biological control reduces the amount of chemical pesticides used for cultivation and includes the other benefits of reduced exposure of workers to chemicals and fewer residues in the environment [10].

The predatory mites can be classified into 4 types, and Type I were subdivided into subtypes to highlight the specificity in relation to the pest mite. In this group is $P$. macropilis being a mite of subtype $\mathrm{I}-\mathrm{a}$, that is, specialized in predating the genus Tetranychus. Type II mites are those that are selective of Tetranychidae mites but can also be fed from other genera or group of mites such as Tydeoidea, Eriophyidae, Tarsonemidae or even pollen. Although some authors question that N. californicus should be classified as Type III of predatory mites, they are maintained as Type II because they are associated with mites that produce large amounts of webs such as T. urticae. Type III of predatory mites does not get along with mites that produce webs because they can often get stuck in them. These Type III are those that are generalists and have also been subdivided into subtypes according to their habitat. Type IV of predatory mites are those for which pollen is an important part of the diet [11].

In Europe and the United States of North America, the cost of biological control methods may be similar to the cost of chemical control, particularly when the number of predators released is based on an estimation of the pest density, which makes biological control an attractive alternative for pest management [12] [13].

However, for biological control with predatory mites to be a viable solution in the productive sector, the biological characteristics and efficiency of these predaceous mites for pest control must be determined, and therefore investigations are required of the interactions between predatory mites.

Therefore, the objective of this study was to investigate the biological control of the two-spotted spider mite, T. urticae, on rosebushes growing in a greenhouse with the individual or joint release of the predatory mites, P. macropilis and $N$. californicus.

\section{MATERIAL AND METHODS}

The study was conducted at the Acarology Laboratory of the Empresa de Pesquisa Agropecuária de Minas Gerais EPAMIG-Sul de Minas - Centro de Pesquisa em Manejo Ecológico de Pragas e Doenças de Plantas - EcoCentro, Lavras, MG, Brazil, under the controlled conditions of $25 \pm 2{ }^{\circ} \mathrm{C}, 70 \% \pm 10 \% \mathrm{RH}$, and a $14 \mathrm{~h}$ photophase and, in a greenhouse at the Experimental Station of EPAMIG, also in Lavras.

Both predatory mites, P. macropilis and N. californicus, and the pest mite T. urticae were obtained from the Instituto Federal de Educação, Ciência e Tecnologia do Sul de Minas - Campus de Inconfidentes, Minas Gerais, Brazil.

\subsection{Rearing of the two-spotted spider mite}

Uncovered petri dishes $(15 \mathrm{~cm}$ in diameter) were used with $1 \mathrm{~cm}$ thick foam occupying the entire bottom surface of each dish. The foam was kept moist with distilled water. A jack bean leaflet [Canavalia ensiformis L. (DC), Fabaceae] was placed on top of the foam and, to prevent the mites from escaping and better preserve the leaflet, the leaflet was surrounded by strips of cotton that were also in contact with the damp foam. Pest mite, T. urticae, were placed on top of the jack bean leaflets, which were replaced weekly [14].

\subsection{Rearing of predatory mites}

Arenas of black flexible PVC plastic sheets $(26 \times 22 \mathrm{~cm})$ were placed on Styrofoam of equal size, and these were placed on water in plastic trays $(32 \times 26.5 \times 5.5 \mathrm{~cm})$. Cotton in contact with water from the tray was placed around the Styrofoam and the arena and was used to prevent the escape of mites, in addition to preserving the jack bean leaves. Leaves were placed in 
the arenas with the petiole under the damp cotton and were infested with T. urticae to provide food for the predatory mites; as the leaves withered other new leaves infested with $T$. urticae were placed on the old leaves [14].

\subsection{Biological control assay}

The experiment investigating biological control of the two-spotted spider mite, T. urticae, was conducted between September and November 2012 in a greenhouse with a transparent plastic cover and fine mesh fabric on the sides. White rosebushes (Rosa alba L., Rosaceae) with table grafting and approximately 4 years old in 22 liter pots were used. A mixture of ravine soil, manure, and sand was used as the substrate. During the growing cycle, the necessary cleaning and pruning were conducted to avoid affecting the population of predatory mites during release periods.

The experiment consisted of five treatments with five replicates each of five plants/treatment in an experimental design of randomized blocks, to avoid any variation between treatments: 1 - control group, rosebushes only with T. urticae, 2 rosebushes with $T$. urticae and $N$. californicus, 3 - rosebushes with $T$. urticae and $P$. macropilis, 4 - rosebushes with $T$. urticae, N. californicus, and, after 4 weeks, P. macropilis, and 5 - rosebushes with T. urticae, N. californicus, and P. macropilis. To prevent dispersal of pest mites and predatory mites, rosebushes were placed individually, isolated from each other, in wood cages, $0.60 \times 0.60 \times 1.50 \mathrm{~m}$, covered with voil cloth fabric.

First, rosebushes were infested with 20 female two-spotted spider mites per plant. The first release of predatory mites was conducted nine days after the pest mite infestation [15].

In treatment 1 (control group), predatory mites were not released; and, in treatments 2 (N. californicus vs. T. urticae) and 3 (P. macropilis vs. T. urticae), a total of 16 female predatory mites were released at two per week for eight weeks. In treatment 4 ( $N$. californicus vs. T. urticae, and, after 4 weeks, P. macropilis), initially, only two N. californicus were released per week during the first month of evaluation for a total of eight female predatory mites, assuming that infestation by $T$. urticae would still be low, and then, after this period, only two P. macropilis were released per week for a total of eight predatory mites of this species, assuming that this infestation by T. urticae would already be higher; thus a total of 16 female predatory mites were released, with eight of each species. In treatment 5 ( N. californicus $+P$. macropilis vs. T. urticae), two predatory mites were released weekly, one of each species.

Females of the predatory mites were transferred with a fine-tipped brush to leaves with signs of pest mite infestation between 8:00 a.m. and 12:00 p.m. The releases were conducted over two months, for a total of eight releases.

Rosebush leaflets were collected weekly beginning a week after the two-spotted spider mite infestation until the end of the experiment. A total of six leaflets per plant were collected each week, with two randomly selected from each part of the plant (apical, middle, and basal). Leaflets collected from each part were identified, separated, and transferred immediately to the laboratory properly packaged in paper bags, wrapped with polyethylene bags, and placed in a Styrofoam cooler containing ice. A stereomicroscope was used to count the eggs and any type of active stage of the pest mite on the leaflets.

\subsection{Statistical analyses of the biological control assay}

Because the data for analysis were mite counts (eggs and any other type of active stage of the pest mite), a negative binomial regression model, which accounts for the effect of over dispersion, was considered a logarithmic linkage function with the systematic components given by the following: $\eta_{i}=\beta_{0}+\beta_{1} x_{1 i}+\beta_{2} x_{2 i}^{2}+\beta_{3} z_{1 i}+\beta_{4} z_{2 i}+\beta_{5} z_{3 i}+\beta_{6} z_{4 i}$, where $x_{1 i}$ is the temporal effect of the week, $x_{2 i}^{2}$ is the square of the temporal effect of the week, and $z_{j i}(j=1,2,3,4)$ are the categorical variables related to treatments one (control group), two, three, four, and five, respectively. Therefore, the control treatment was use $\mathrm{d}$ as a reference when $z=(0,0,0,0)$. The parameters $\beta_{j}(j=1, \ldots, 6)$ represented the associated effects with each variable, and

the log-linear linkage function $\log { }_{i}={ }_{i}$, where $\mu_{i}$ represents the response variable average $y_{\mathrm{i}}$ in the week $x_{i}$ and in the treatment $z_{j}$. Therefore, the model that related the average number of prey with the $x$ and $z$ variables is given by the following equation (1), with $\varepsilon_{\mathrm{i}}$ the experimental error associated with the ith portion:

$$
\mu_{i}=e^{\beta_{0}+\beta_{1} x_{1 i}+\beta_{2} x_{2 i}^{2}+\beta_{3} z_{1 i}+\beta_{4} z_{2 i}+\beta_{5} z_{3 i}+\beta_{6} z_{4 i}}+\varepsilon_{i}
$$

The parameters of the model were estimated using the maximum likelihood method [16], and the validation was conducted using the simulated envelope graphic [17]. 
Percentage rates, indicated as $\psi$, were calculated with the objective of measuring the effect of a treatment in comparison with the control group, considering the reference model obtained when $z=(0,0,0,0)$ and the model for a particular $z_{j}$. Percentage rates (or odds ratios) among the models are given by equation (2) [18].

$$
\psi=e^{\beta j}
$$

Given these specifications, based on the model proposed in equation (1), scenarios were organized with the following treatments: scenario 1, comparison between the control group and the other treatments; scenario 2, predator N. californicus released individually or released with P. macropilis; scenario 3, predator P. macropilis released individually or released with N. californicus; and scenario 4, comparison between the predatory mites $N$. californicus and P. macropilis, both individually released. Statistical analyses were all conducted with the R statistical software package [19].

\section{RESULTS AND DISCUSSION}

\subsection{Biological control assay}

For further clarification and interpretation of results, the odds ratios and parameters of significance are described in Tables 1 - 5, with the estimations of parameters of the adjusted models as the control group. Therefore, results that corroborated the validation of the model initially allowed interpretation of all adjusted models for the scenarios 1 through 4, as previously described, as presenting satisfactory adjustment quality (Fig. 1).

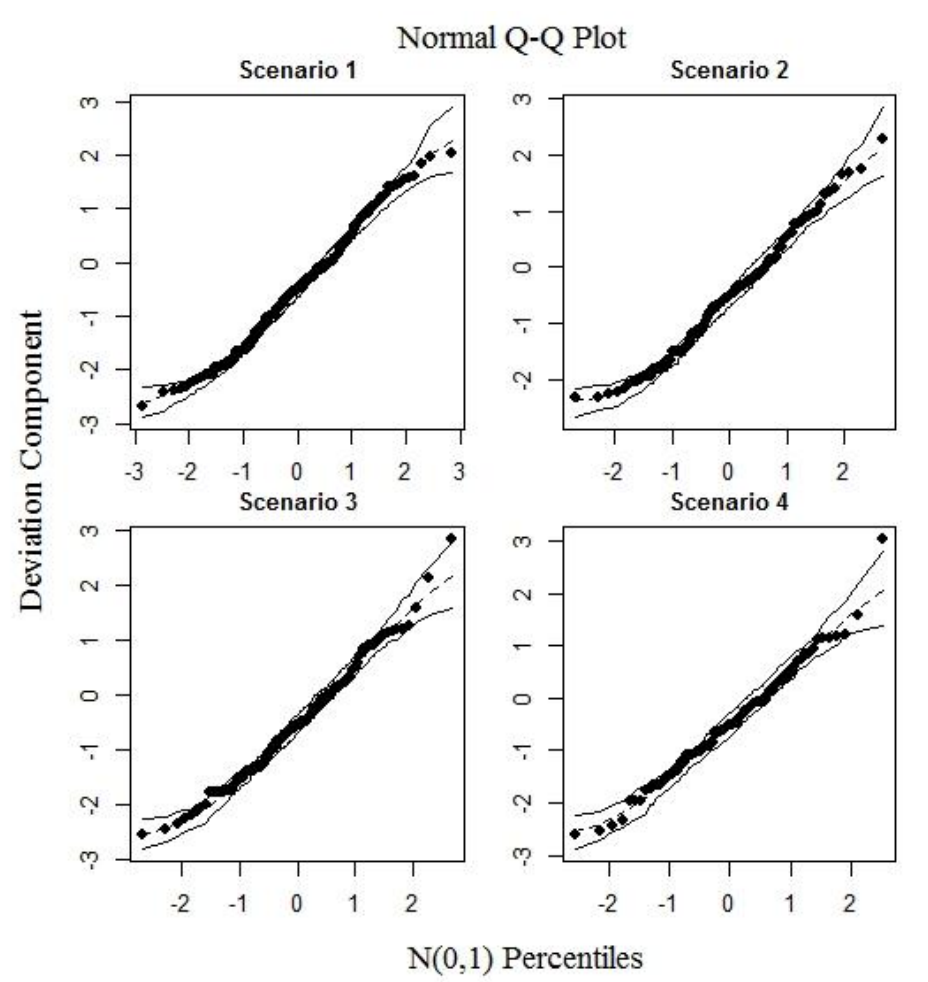

Figure 1. SimUlated ENVELOPES BASED ON THE NEgative BinOMINAl LOG-LiNEAR MODEL, AdJUSTED to the Data of the Number of Prey T. URticae Predated on Six Leaflets for the Following: SCEnario 1 (CONTrol Group Vs. Other TreatMentS); SCEnario 2 (Predatory Mite $\boldsymbol{N}$. CALIFORNICUS RELEASED INDIVIDUALLY OR RELEASED WITH P. MACROPILIS); SCENARIO 3 (PREDATORY MITE P. MACROPILIS RELEASED INDIVIDUALLY OR RELEASED WITH $N$. CALIFORNICUS), AND SCENARIO 4 (COMPARISON BETWEEN PREDATORY MITES N. CALIFORNICUS AND P. MACROPILIS, BOTH INDIVIDUALLY RELEASED)

In the comparison with treatment 1 (control group, only $T$. urticae), the release of the two predatory mites individually or in combination significantly reduced the number of pest mites (Table 1; Fig. 2, Scenario 1). Notably, in treatments 3 ( $P$. macropilis vs. T. urticae) and 5 (N. californicus + P. macropilis vs. T. urticae), both with the predatory mite $P$. macropilis from the beginning of the experiment, the expected number of pest mites was reduced by approximately $93 \%$ and $92 \%$, respectively, compared with the control group (Table 1). 


\section{TABLE 1}

PARAmeter Estimations of the Negative BinOMinal Regression MOdel, ResPective Standard

Errors and Percentage Rates $\psi$ among the Treatments $J(J=2,3,4,5)$, AND the Reference (TREAT 1= T. URTICAE ONLY) FOR THE NUMBER OF T. URTICAE ON SIX LEAFLETS

\begin{tabular}{|c|c|c|c|c|c|c|}
\hline Variable & Parameter & Estimation & Standard error & $\boldsymbol{p}$-value & $\psi$ & $\mathbf{1}$ - $\boldsymbol{\psi}(\boldsymbol{\%})$ \\
\hline Intercept & $\beta_{0}$ & 4.2277 & 0.4409 & $<0.0001$ & - & - \\
\hline Week & $\beta_{1}$ & 1.5246 & 0.1797 & $<0.0001$ & - & - \\
\hline Week2 & $\beta_{2}$ & -0.1631 & 0.0175 & $<0.0001$ & - & - \\
\hline Treat2 & $\beta_{3}$ & -1.9508 & 0.3230 & $<0.0001$ & 0.1422 & 85.78 \\
\hline Treat3 & $\beta_{4}$ & -2.6620 & 0.3251 & $<0.0001$ & 0.0698 & 93.02 \\
\hline Treat4 & $\beta_{5}$ & -1.7084 & 0.3229 & $<0.0001$ & 0.1812 & 81.88 \\
\hline Treat5 & $\beta_{6}$ & -2.5081 & 0.3234 & $<0.0001$ & 0.0814 & 91.86 \\
\hline Dispersion & $\phi$ & 0.4276 & 0.0379 & - & - & - \\
\hline
\end{tabular}

${ }^{1}$ Treat $2=T$. urticae $+N$. californicus, Treat $3=T$. urticae $+P$. macropilis, Treat $4=T$. urticae $+N$. californicus and, after 4 weeks, release of $P$. macropilis, Treat $5=T$. urticae $+N$. californicus $+P$. macropilis

With treatment 1 as the control group (only T. urticae), the incidence of the pest was higher near the fifth week (4.7) compared with the other treatments (Table 2, Scenario 1).

TABLE 2

EXPECTED MAXIMUM NUMBERS OF T. URTICAE ON SIX LEAFLETS OBTAINED FROM THE ADJUSTED MODELS FOR SCENARIOS 1 TO 4

\begin{tabular}{|c|c|c|c|c|}
\hline & Scenarios & Treatment $^{1}$ & Maximum & Week \\
\hline \multirow{5}{*}{1} & \multirow{5}{*}{ Comparison between the control group and all other treatments } & Treat1 & $2,418.90$ & 4.70 \\
\hline & & Treat2 & 343.90 & 4.70 \\
\hline & & Treat3 & 168.90 & 4.70 \\
\hline & & Treat4 & 438.20 & 4.70 \\
\hline & & Treat5 & 196.90 & 4.70 \\
\hline \multirow{3}{*}{2} & \multirow{3}{*}{$\begin{array}{l}\text { Predatory mite } N \text {. californicus released individually or released with } P \text {. } \\
\text { macropilis }\end{array}$} & Treat2 & 394.21 & 4.60 \\
\hline & & Treat4 & 573.53 & 4.60 \\
\hline & & Treat5 & 217.08 & 4.60 \\
\hline \multirow{3}{*}{3} & \multirow{3}{*}{$\begin{array}{l}\text { Predatory mite } P . \text { macropilis released individually or released with } N . \\
\text { californicus }\end{array}$} & Treat3 & 150.26 & 4.20 \\
\hline & & Treat4 & 789.18 & 4.20 \\
\hline & & Treat5 & 185.76 & 4.20 \\
\hline \multirow{2}{*}{4} & \multirow{2}{*}{$\begin{array}{c}\text { Comparison between predatory mites } N \text {. californicus and } P \text {. macropilis, } \\
\text { both released individually }\end{array}$} & Treat2 & 585.86 & 4.12 \\
\hline & & Treat3 & 176.35 & 4.12 \\
\hline
\end{tabular}

${ }^{I}$ Treat $1=$ Control $($ T. urticae $)$, Treat $2=$ T. urticae $+N$. californicus, Treat $3=$ T. urticae $+P$. macropilis, Treat $4=T$. urticae $+N$. californicus and, after 4 weeks, release of $P$. macropilis, Treat $5=T$. urticae $+N$. californicus $+P$. macropilis

Specifically regarding treatment 2 in which the predatory mite $N$. californicus was released individually, and using this treatment as the control group, no significant difference was observed between the treatments when the predatory mite $P$. macropilis was released 4 weeks after the release of N. californicus (treatment 4) (Table 3; Fig. 2, Scenario 2).

TABLE 3

PARAMETER Estimations of the Negative BinOMinal Regression MODEl, ResPeCtive StANDARD Errors and Percentage Rates $\psi$ AMong Treatments $J(J=4,5)$, AND the Control Group (Treat $2=T$. URTICAE + N. CALIFORNICUS) FOR THE NUMBER OF T. URTICAE ON SIX LEAFLETS

\begin{tabular}{|c|c|c|c|c|c|c|}
\hline Variable & Parameter & Estimation & Standard error & $\boldsymbol{p}$-value & $\boldsymbol{~}$ & $\mathbf{1 - \psi}(\boldsymbol{\%})$ \\
\hline Intercept & $\beta_{0}$ & 1.9028 & 0.5698 & 0.0008 & - & - \\
\hline Week & $\beta_{1}$ & 1.7563 & 0.2455 & $<0.0001$ & - & - \\
\hline Week2 & $\beta_{2}$ & -0.1893 & 0.0240 & $<0.0001$ & - & - \\
\hline Treat4 & $\beta_{5}$ & 0.3749 & 0.3420 & 0.2729 & 1.4549 & - \\
\hline Treat5 & $\beta_{6}$ & -0.5966 & 0.3427 & 0.0817 & 0.5507 & 44.93 \\
\hline Dispersion & $\phi$ & 0.3824 & 0.0447 & - & - & - \\
\hline
\end{tabular}

${ }^{1}$ Treat4 $=$ T. urticae $+N$. californicus and, after 4 weeks, release of $P$. macropilis, Treat5 $=$ T. urticae $+N$. californicus + P. macropilis 
With treatment 3 (P. macropilis vs. T. urticae) as the control group, when P. macropilis was released only after the fourth week in treatment four ( $N$. californicus and, after 4 weeks, the release of P. macropilis vs. T. urticae), the average number of pest mites was approximately 5-fold greater than that in the control (Table 4; Fig. 2, Scenario 3). Compared with the control (treatment 3), such a large difference in prey was not observed in treatment 5 (P. macropilis + N. californicus vs. T. urticae), with both predators released in combination from the beginning of the experiment (Table 4; Fig. 2, Scenario 3). Therefore, the predatory mite $P$. macropilis was highly efficient in the predation of the two-spotted spider mite, at either low or high prey density.

TABLE 4

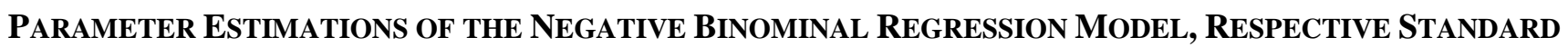
Errors and Percentages Rates $\psi$ among Treatments J $(J=4,5)$, AND The Control Group (TREAT $3=T$. URTICAE + P. MACROPILIS) FOR THE NUMBER OF T. URTICAE ON SIX LEAFLETS

\begin{tabular}{|c|c|c|c|c|c|c|}
\hline Variable & Parameter & Estimation & Standard error & $p$-value & $\psi$ & 1- $\psi(\%)$ \\
\hline Intercept & $\beta 0$ & 1.9002 & 0.5355 & 0.0004 & - \\
\hline Week & $\beta 1$ & 1.4908 & 0.2311 & $<0.0001$ & - \\
\hline Week2 & $\beta 2$ & -0.1785 & 0.0227 & $<0.0001$ & - \\
\hline Treat4 & $\beta 5$ & 1.6586 & 0.3217 & $<0.0001$ & 5.2519 & - \\
\hline Treat5 & $\beta 6$ & 0.2121 & 0.3231 & 0.5116 & 1.2362 & - \\
\hline Dispersion & $\phi$ & 0.4367 & 0.0519 & - & - \\
\hline
\end{tabular}

${ }^{1}$ Treat4 $=T$. urticae $+N$. californicus and, after 4 weeks, release of $P$. macropilis, Treat5 $=$ T. urticae $+N$. californicus + P. macropilis

With treatment 2 ( N. californicus vs. T. urticae) as the control group, in the comparison of the two predators in treatments 2 and 3 (P. macropilis vs. T. urticae), prey numbers were lower with the predator P. macropilis in treatment 3.

Thus, similar to in Fig.2 Scenario 3, the predatory mite $P$. macropilis performed better in reducing prey mite numbers than the predatory mite N. californicus (Table 5; Fig. 2, Scenario 4), and, compared with N. californicus, the expected number of two-spotted spider mites was reduced by approximately $70 \%$ in the fourth week of the evaluation (Table 5).

TABLE 5

Parameter Estimations Of The Negative Binominal Regression Model, ResPective Standard Errors And Percentages Rates $\psi$ For Treatment $J(J=3)$, And The Control Group (Treat $2=$ T. URTICAE + N. CALIFORNICUS) FOR THE NUMBER OF T. URTICAE ON SIX LEAFLETS

\begin{tabular}{|c|c|c|c|c|c|c|}
\hline Variable & Parameter & Estimation & Standard error & p-value & $\psi$ & $1-\psi(\%)$ \\
\hline Intercept & $\beta 0$ & 2.7234 & 0.6194 & $<0.0001$ & - & - \\
\hline Week & $\beta 1$ & 1.7652 & 0.2784 & $<0.0001$ & - & - \\
\hline Week2 & $\beta 2$ & -0.2134 & 0.0275 & $<0.0001$ & - & - \\
\hline Treat $^{1}$ & $\beta 3$ & -1.2006 & 0.3158 & $<0.0001$ & 0.3010 & 69.90 \\
\hline Dispersion & $\phi$ & 0.4603 & 0.0665 & - & - & - \\
\hline
\end{tabular}

\footnotetext{
${ }^{I}$ Treat3 $=$ T. urticae + P. macropilis
} 


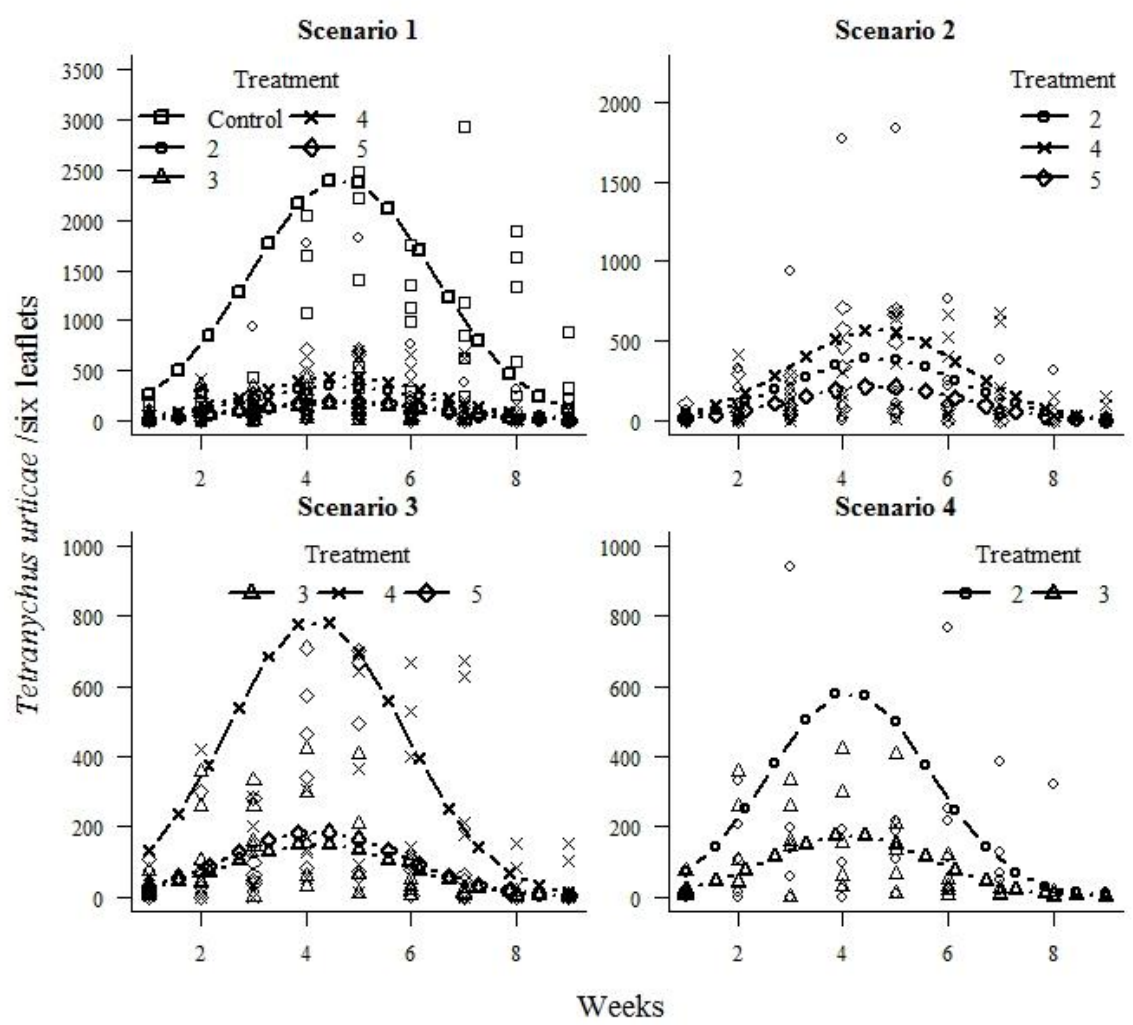

Figure 2. Adjusted Models For Scenarios 1, 2, 3, AND 4. SCEnARio 1, Comparison Between The Control Group And All Other Treatments; Scenario 2, Predatory Mite N. Californicus

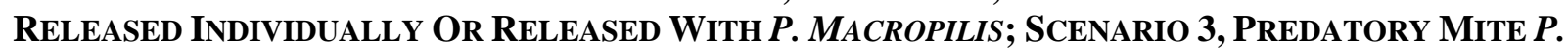
MACROPILIS RELEASED INDIVIDUALLY OR RELEASED WITH N. CALIFORNICUS; SCENARIO 4, COMPARISON BetWEen PREDATORY Mites N. CALIFORNICUS ANd P. MACROPILIS, BOTH RELEASED INDIVIDUALLY. Treatment 1 Control Group, Rosebushes Only With T. urticae; TREATMENT 2 ROSEBUSHES WITH T. urticae AND N. californicus; TREATMENT 3 ROSEBUSHES WITH T. urticae AND P. macropilis; TREATMENT 4 ROSEBUSHES WITH T. urticae, N. californicus, AND, AFTER 4 WEEKS, P. macropilis AND TREATMENT 5 ROSEBUSHES WITH T. urticae, $N$. californicus AND P. macropilis.

As illustrated in Tables 1 and 2 and Fig. 2, after the fourth week of the release of the predatory mites, all treatments were significantly different from the control group, with predatory mites reducing the populations of $T$. urticae to very low levels at the end of the experiment. These results are similar to those found for strawberry plants (Fragaria spp., Rosaceae) [20] on which a population of two-spotted spider mite began to decrease 20 days after the release of $P$. macropilis.

In a comparison of different releases of $N$. californicus for the control of the European red mite Panonychus ulmi (Koch) (Acari: Tetranychidae) in apple trees [Malus domestica (Borkh.) Borkh., Rosaceae], the release of 15 mites per $\mathrm{m}^{2}$ provided the most efficient control, and therefore the most predatory mites provided the greatest control of the pest mite [21]. A similar result was observed in the biological control of the two-spotted spider mite on rosebushes with $N$. californicus 1 month following the release of the predatory mite at densities that varied from 0 to 28 , and, with the increase in predatory mite density, the decrease in the number of two-spotted spider mites on the leaflets was greater [14].

A study on the potential of $N$. californicus to control T. urticae on rosebushes found that an initial density of ten predatory mites $/ \mathrm{m}^{2}$ was not sufficient to control the pest, however, when 20 predatory mites $/ \mathrm{m}^{2}$ were used, although the infestation of $T$. urticae was larger, the pest mite was controlled rapidly [22].

Predatory mite/prey ratios of 1:5, 1:7.5, and 1:10 for $N$. californicus provided good control of $T$. urticae on strawberry and prevented the pest from causing damage that exceeded the economic threshold, which was 50 mites/leaflet [23].

Additionally, when $N$. californicus was released at predatory mite/prey ratios between 1:5 and 1:10, this predatory mite was an effective biological control agent of $T$. urticae on strawberry plants in the field and in greenhouse conditions and maintained the pest population at low levels for long periods [24]. 
For control of the two-spotted spider mite on geranium (Geranium spp., Geraniaceae), a week after release, the predatory mite $P$. persimilis at predatory mite/prey ratios of 1:4 and 1:20 caused a significant decrease in numbers of $T$. urticae and maintained low levels of the pest, and the plants suffered less damage [25].

In the present study, the results show as the number of predatory mites released on the plants increased, the number of pest mites in the treatments decreased. However, the number of pest mites also decreased in the control group, which was unexpected in the absence of predatory mites. As a possible explanation, when the number of pest mites increases significantly, these mites have a tendency to disperse and search for healthier plants [26], because the control treatment plants were very weak when compared to plants whose treatments had predatory mites. This phenomenon was observed in the control group, and, in an attempt to disperse, the mites concentrated on the leaves at the top of plants and on the floral buds. Thus, although the density of pest mites on the plants in control treatment was high, the pest density was likely underestimated because leaves were collected from all parts of the plants and not only from the most affected regions. After the release of $N$. californicus, $P$. persimilis, and $N$. californicus $+P$. persimilis on gerbera (Gerbera spp., Asteraceae) growing in a greenhouse, each species of predatory mite individually decreased the population of Tetranychus cinnabarinus (Boisduval, 1867) (Acari: Tetranychidae) to zero [27]. In the present study, a similar result was also observed for $N$. californicus and P. macropilis on T. urticae on rosebushes. When generalist and specialist predatory mites are released in combination, intraspecific and interspecific competition occurs, leading researchers to conclude that only one predatory mite species must be released at a time, with each predatory mite considered separately before selection [27]. However, in the present study, releasing both predatory mite species in combination was as viable as the individual release of only one of the species.

Although the individual release of $P$. persimilis is a favorable strategy for the immediate control of $T$. cinnabarinus in the greenhouse [27] [28], the long-term control of pest mites was improved by the sequential or combined release of $N$. californicus and P. persimilis, which is also valid for the control of T. urticae [29]. When an alternative food is available, e.g., pollen, $N$. californicus can be released to persist before the occurrence of pest mites or, in the absence of an alternative food, can be released as soon as the pest is detected. As soon as the densities of the pest increase and N. californicus can no longer control pest mites, $P$. persimilis can be released [27].

A similar approach could be used with $P$. macropilis and $N$. californicus for control of the two-spotted spider mite on rosebushes. Phytoseiulus macropilis has a high rate of predation, and this predatory mite species can be used to locate $T$. urticae at long distances in infested strawberry plants through volatile substances induced by the herbivory of T. urticae [20]. By contrast, the predator $N$. californicus can function as a stabilizer, because this predator survives better under conditions of low prey densities and may be more resistant to chemical products [30].

For the conditions of this study, both species of predatory mites, P. macropilis and $N$. californicus, were efficient in the control of the two-spotted spider mite, T. urticae, on rosebushes growing in the greenhouse. Thus, in situations close to these, both the release of $N$. californicus and the release of $P$. macropilis alone could be recommended without the need for joint release. However, $P$. macropilis would be a more viable option, since it reduced a greater number of pests when compared to N. californicus. However, one should not forget to analyze each case and situation according to their need for control.

\section{CONCLUSIONS}

The predatory mites $N$. californicus and P. macropilis were effective biological control agents of the two-spotted spider mite, T. urticae, on rosebushes growing in the greenhouse, released individually or in combination.

When the predatory mites were released as a single species, P. macropilis was more efficient in the biological control of $T$. urticae than $N$. californicus, at either low or high prey density, but the $N$. californicus can survive for longer in the absence of prey or in its low presence, for being a generalist predatory mite.

\section{ACKNOWLEDGEMENTS}

The Conselho Nacional de Desenvolvimento Científico e Tecnológico - CNPq is acknowledged for financial support and providing scholarships.

\section{REFERENCES}

[1] Ibraflor - Instituto Brasileiro de Floricultura. 2015. Available from: <http://www.ibraflor.com/ publicacoes/vw.php? cod=235>. Accessed in: June 2015. 
[2] P.R.C. Landgraf and P.D.D. Paiva. 2009. Production of cut flowers in the state of Minas Gerais. Ciência e Agrotecnologia, Lavras, 33 (1):120-126.

[3] J.G. Barbosa; J.A.S. Grossi; J.M. Santo; K. Pivetta and F.L. Finger. 2007. Rosas (Rosa spp.). In: T.J. Paula Junior and M. Venzon. 101 culturas: manual de tecnologias agrícolas. EPAMIG, Belo Horizonte, pp 675-682.

[4] L.M. Carvalho; V.H.P. Bueno; L.V.C. Santa-Cecília; R.A. Silva and P.R. Reis. 2009. Pragas na floricultura: identificação e controle. Informe Agropecuário, 30 (249): 36-46.

[5] C.A.M. Severino. 2007. Controle biológico de pragas e doenças em floricultura. Salvador, Rede de Tecnologia da Bahia. 24p. (Dossiê Técnico).

[6] L.M. Carvalho; K. Almeida; T.C. Taques; C.S.A. Soares; E.F.A. Almeida and S.N. Reis. 2012. Manejo de pragas em cultivo de roseira de sistema de produção integrada e sistema convencional. Bioscience Journal, 28 (6):938-944.

[7] F.Z.V. Torres; G.A. Carvalho; J.R. Souza and L.C.D. Rocha. 2007. Seletividade de inseticidas a Orius insidiosus. Bragantia, 66 (3):433-439.

[8] A.C. Busoli. 1992. Uso de enxofre em citros e dinâmica populacional de cochonilhas e ácaros. Laranja, 13 (1):353- 395.

[9] J.A. Guimarães; M. Michereff Filho; F.A.M. Graciano; A.M.R. Junqueira and R.S. Liz. 2010. Ácaros predadores no manejo do ácaro rajado em morangueiro no Distrito Federal. Brasília, EMBRAPA, 7p Comunicado Técnico, 76).

[10] Promip - Programas de Manejo Integrado de Pragas. 2015. Available from: <http://www.promip.agr.br/>. Accessed in: 10 June 2015.

[11] J.A. McMurtry; G.J. Moraes and N.F. Sourassou. 2013. Revision of the lifestyles of phytoseiid mites (Acari: Phytoseiidae) and implications for biological control strategies. Systematic \& Applied Acarology, 18 (4):297-320.

[12] J.C. Van Lenteren. 2005. Controle biológico: uma proposta atrativa para o manejo de pragas. Informe Agropecuário, 26 (225):4-8.

[13] G.P. Opit; J. Perret; K. Holt; J.R. Nechols; D.C. Margolies and K.A. Williams. 2009. Comparing chemical and biological control strategies for two spotted spider mites (Acari: Tetranychidae) in commercial greenhouse production of bedding plants. Journal Economy Entomology, 102 (1):336-346.

[14] G.C. Souza-Pimentel; P.R. Reis; E.C. Silveira; P.P. Marafeli; E.A. Silva and H.B. Andrade. 2014. Biological control of Tetranychus urticae (Tetranychidae) on rosebushes using Neoseiulus californicus (Phytoseiidae) and agrochemical selectivity. Revista Colombiana de Entomologia, 40 (1):80-84.

[15] A. Walzer and P. Schausberger. 2005. Are two better than one? Combined effects of the predatory mites Phytoseiulus persimilis and Neoseiulus californicus (Acari: Phytoseiidae) on spider mites control. IOBC /WPRS Bulletin, 28 (1):309-312.

[16] J. Jiang. 2007. Linear and generalized linear mixed models and their applications. Springer Series in Statistics. New York, 119-230.

[17] C.E. McCulloch; S.R. Searle and J. M. Neuhaus. 2008. Generalized, linear, and mixed models, $2^{\text {nd }}$ ed., John Wiley Sonc Inc., USA, $424 \mathrm{p}$.

[18] P. Cummings. 2009. Methods for estimating adjusted risk ratios. The Stata Journal, 9 (2): 175-196.

[19] R Development Core Team. 2014. R: a language and environment for statistical computing. Vienna, R Foundation for Statistical Computing. Available from: <http://www.r-project.org>. Accessed in: 1 March 2014.

[20] H. Oliveira; M.A.M. Fadini; M. Venzon; D. Rezende; F. Rezende and A. Pallini. 2009. Evaluation of the predatory mite Phytoseiulus macropilis Banks (Acari: Phytoseiidae) as a biological control agent of the twospotted spider mite on strawberry plants under greenhouse conditions. Experimental \& Applied Acarology, 47:275-283.

[21] L.B. Monteiro; A. Doll and L.F. Boeing. 2008. Densidade de Neoseiulus californicus (McGregor, 1954) (Acari: Phytoseiidae) no controle do ácaro-vermelho da macieira, Fraiburgo - SC. Revista Brasileira de Fruticultura, 30 (4):902-906.

[22] M.R. Bellini. 2008. Manejo de Tetranychus urticae (Acari: Tetranychidae) em plantas ornamentais. 138p. Tese (Doutorado em Ecologia Aplicada) - Escola Superior de Agricultura Luiz de Queiroz, Piracicaba, 2008.

[23] N.M. Greco; N.E. Sánchez and G.G. Liljesthröm. 2005. Neoseiulus californicus (Acari: Phytoseiidae) as a potential control agent of Tetranychus urticae (Acari: Tetranychidae): effect of pest/predator ratio on pest abundance on strawberry. Experimental \& Applied Acarology, 37:57-66.

[24] A.B. Fraulo and O.E. Liburd. 2007. Biological control of two spotted spider mite, Tetranychus urticae, with predatory mite, Neoseiulus californicus, in strawberries. Experimental \& Applied Acarology, 43:109-119.

[25] G.P. Opit; J.R. Nechols and D.C. Margolies. 2004. Biological control of twospotted spider mite, Tetranychus urticae Koch (Acari: Tetranychidae), using Phytoseiulus persimilis Athias-Henriot (Acari: Phytoseiidae) on ivy geranium: assessment of predator release ratios. Biological Control, 29:445-452.

[26] G.J. Moraes and C.H.W. Flechtmann. 2008. Manual de acarologia: acarologia básica e ácaros de plantas cultivadas no Brasil. Ribeirão Preto: Holos, 288p.

[27] P. Schausberger and A. Walzer. 2001. Combined versus single species release of predaceous mites: predator-predator interactions and pest suppression. Biological Control, 20: 269-278.

[28] I. Cakmak; A. Janssen; M.W. Sabelis and H. Baspinar. 2009. Biological control of an acarine pest by single and multiple natural enemies. Biological Control, 50:60-65.

[29] E.M. Rhodes; O.E. Liburd; C. Kelts; S.I. Rondon and R.R. Francis. 2006. Comparison of single and of combination treatments of Phytoseiulus persimilis, Neoseiulus californicus, and Acramite (bifenazate) for control two spotted spider mites in strawberries. Experimental \& Applied Acarology, 39:213-225.

[30] J. Van Schelt. 1999. Biological control of sweet pepper pests in the Netherlands. IOBC/WPRS Bulletin, 22 (1):217-220. 